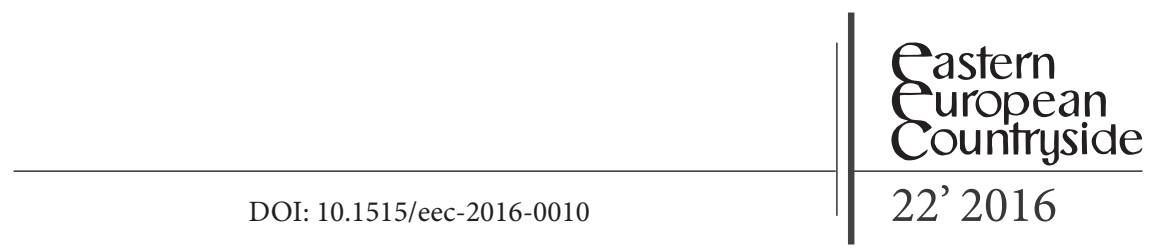

Bazyli Czyżewski $i^{1}$ Jan Polcyn ${ }^{2}$

${ }^{1}$ Poznań University of Economics, Poland

${ }^{2}$ Stanisław Staszic University of Applied Sciences in Piła, Poland

\title{
Education Quality and its Drivers in Rural Areas of Poland
}

\begin{abstract}
A two-stage study was carried out. Firstly, a pioneering attempt was made to measure the quality of education in rural areas of Poland, by county (powiat), using a synthetic indicator. Secondly, the socioeconomic determinants of that quality were modelled. A strength of this study is the fact that it covers the entire population of the given type of administrative units. The analysis served to verify the hypothesis that exogenic socioeconomic factors are key to the effectiveness of the educational process in rural areas. It was shown that in Poland the theories of polarised development are more applicable than those of endogenic development. There was observed an inversely proportional effect from the centre-periphery axis on education quality, but, above all, the effect of several gravitational systems, in which there occurs exogenic diffusion of the results of economic growth and progress from the present and former provincial capitals.
\end{abstract}

Keywords: education quality, rural areas, determinants of education quality 


\section{Introduction}

Education is perceived as a key component that builds a society's human capital. Formal education is identified as one of the phases of formulation of human capital. The human capital of a society may make a positive contribution to regional development, but may also be a cause of regional differentiation, which goes on to produce an increase in social inequalities (Jabłoński 2011: 81-103; Martins, Pereirab 2004: 355-371). Having regard for the level of expenditure on education (approximately 5\% of GDP) and the importance of education for the development of human capital, it is necessary constantly to seek methods of improving the quality of education at various levels. Rural areas may be particularly susceptible to differentiation in education quality. In such areas, there may occur difficulties in accessing cultural goods and greater difficulties related to the jobs market; they also have lower indices for the percentage of the population with high school and college education. In the literature on regional development in the countries of Central and Eastern Europe, it is pointed out that, on the one hand, mechanisms of convergence lead to an equalisation of levels of development between countries of the region, in accordance with the mechanisms described by neoclassical economics (capital accumulation models), while, on the other hand, processes of country-internal regional divergence occur in accordance with the theory of polarised development (Smętkowski 2013: 145-155). This applies particularly to rural areas and regions where agriculture is the dominant function. One of its key symptoms is the drainage of human capital away from rural areas through the mono- or polycentric metropolitan development of the regions. According to the cited work of Smętkowski (2013: 145-155), in the countries of Central and Eastern Europe the "metropolitan" component of regional development explains more than one third of the variance of all factors in that development, and is most strongly correlated with human capital resources, expressed partly in terms of education quality. The cited author also shows that metropolitan areas develop in an endogenic fashion, while the development of non-metropolitan (rural) areas is exogenic, resulting from the diffusion of progress even from distant metropolises.

The literature contains only a few reports concerning the effectiveness of education which take into account the quality of educational processes relating to rural areas. Some sociologists believe that the problem of education 
quality in the sense of the results of education and educational value added (EVA) is so complex and multilayered that it is not possible to speak of the determinants of that quality, and that the problem can only be treated in a holistic manner. In response to such claims, the present authors have attempted to make a multidimensional and, at the same time, comprehensive evaluation of education quality in the set of all non-metropolitan counties (powiats) in Poland, having regard for the complex vector of socioeconomic factors, as well as their exogenic nature, as asserted in the cited literature.

Based on the above considerations, the following research goals were formulated:

1. To measure education quality in rural areas of Poland, by county, using a specially constructed synthetic indicator.

2. To identify a set of social and economic determinants which best explain the variation in education quality among the entire population of non-metropolitan counties in Poland.

The realisation of these goals served to verify the hypothesis that exogenic socioeconomic factors are key to the effectiveness of the educational process (the education production function) in rural areas of Poland.

\section{Survey of the literature on determinants of education quality}

An important objective of the planned analyses is the identification of factors determining education quality. A literature survey brings to light the following factors as determinants of education quality: pupil-teacher ratio, regional culture, social capital, quality of teaching staff, expenditure on teachers' salaries, schools' technical equipment, and levels of personal income. Measuring education quality is a complex process which depends on very many factors; therefore, it should be assumed that the determinants listed here do not exhaust the list of factors affecting the quality of educational processes, but merely signal the complexity of the issue.

In relation to the aforementioned determinants of education quality, note should be taken of the favourable effect of a lowering of the pupil-teacher ratio (Benesova, Sanova, Laputkova 2015: 25-33). The effect of this ratio and of the associated quality of education is strongly modified by the culture of the region. It should be noted, in fact, that regional culture modifies the impact of all inputs to education (Cheung, Chan 2008: 698-707). 
A significant element, considered key to the creation of education quality, concerns the teachers and the actions taken to motivate them to better and more effectively work, and also their ability to motivate groups of pupils (Zhou, Cheng 2010: 999-1003). A significant determinant of the quality of teachers' work may be their level of education in combination with professional experience (Atawne, Hoz 2012: 1051-1055; Boyd, Lankford, Loeb, Wyckoff 2011: 439-454; Ballou, Podgursky 2002: 892-912; Kremer 1995: 247-254). In Polish conditions, these factors are reflected in the promotion system to which the teaching profession is subject.

A link may be expected between the quality of teaching staff and their system of remuneration. It is found, however, that teachers' pay is not proportional to the educational results which they achieve (Pritchett, Filmer 1999: 223-239).

Some studies of education quality take into account the standard of schools' technical equipment and pupils' access to computer technologies. These factors are most commonly perceived as strong determinants of education quality (Salim 2013: 2450-2455).

Particular attention is paid in the literature to the level of social capital, linked to higher levels of personal income, as well as ethnic diversity (Rupasingha, Goetz, Freshwater 2002: 139-155). Studies on the impact of social capital on economic growth, based on an extended Solow model, confirm the long-term impact of social capital on income growth (Tatsi, Zafar 2011: 1-50). Other reports provide information on the effect of financial resources on education quality, again revealing a link between education quality and social capital. It must be borne in mind, however, that social capital also affects education quality directly. It is found to impact pupils individually and as a group, bringing better examination results as well as improvement in how pupils feel in the class. Individual pupils' social capital is regarded as more significant than that of the class (Comer 2015: 225-231). In some cases a negative effect of social capital on teaching results can also be observed (Van Rossem, Vermande, Volker, Baerveldt 2015: 669-688). Attention is drawn to the particularly important role of socioeconomic capital in schools attended by students of low socioeconomic status (Allan, Catts 2014: 217-228; Shoji, Haskins, Rangel, Sorensen 2014: 600-613).

Education quality may be influenced by variables characterising socioeconomic factors such as the level of crime. There is found to be an 
inverse correlation between the level of education in society and crime levels (Lochner, Moretti 2004: 155-189).

A significant feature in studies of education quality is peer group influence. Pupils in a difficult socioeconomic situation achieve higher returns from belonging to a positively influential peer group (Schneeweis, WinterEbmer 2005: 387-409).

In considering the socioeconomic context of education quality, control variables used include the percentage of pupils belonging to ethnic minorities, the percentage attending special educational programmes, and the percentage eligible to receive social assistance (Chakraborty 2009: 1-18).

Studies on the effect of pupils' environment on education quality indicate that a significant predictor in this regard is the parents' level of education and the family structure (Babarovic, Burusic, Sakic 2009: 673-695; Kipkorir, Reuben 2015: 792-796).

Social awareness with regard to influence on education quality is reflected in the belief that a greater influence may come from the parents. The impact that parents have on education quality may be strongly linked to their engagement in the functioning of the school (de Kool, Bekkers 2015: 645-659).

There are numerous scientific reports on the link between examination results and the expenditure incurred to support students (Jacques, Brorsen 2002: 997-1002). This may be a very important indication enabling improvement of the quality of educational processes through the focussing of teaching support on groups of students having difficulties in attaining educational success.

Environmental variables may be expressed by means of an index of a pupil's home educational resources, including the number of books and didactic aids such as a computer and a desk for the pupil's own use (Ismail, Cheng 2005: 1-8). Some researchers report a link between pupils' educational results and their family situation, including the parents' income and level of education (Barro, Lee 2001: 465-488).

Education quality may not be a result of the amount of financial expenditure, but may be strongly modified by cultural issues and the ineffectiveness of educational resources (Heyneman 1997: 449-466). Moreover, the educational effects achieved may be very significantly dependent on the availability of school resources (Gamoran, Long 2006). 
Some research reports have given an indication of the significant impact of the socioeconomic environment on education quality (Duncombe, Miner, Ruggiero 1997: 18; Bradford, Malt, Oates 1969: 185-202; Klump, Cabrera 2007: 1-45).

Panel research conducted in Russia indicated that population density has a negative impact on education quality (Verbina, Chowdhury 2004: 489-508).

The measurement of education quality is a complex process. It may be viewed in terms of either the effectiveness of expenditure on education, or an absolute measure of the increase in pupils' knowledge (educational value added). Value added refers to the subjects covered by a system of external examinations. In Polish high schools that system includes the final matura examination, as well as external vocational examinations at vocational high schools. Values obtained from the external examination system, however, indicate only the individual progress made by pupils in relation to their intellectual capabilities, and include several values relating to educational value added in Polish language, mathematics, and subjects in the humanities group and the mathematics and science group. The number of measures obtained as a result of external examination means that it is not possible to make a transparent comparison of the analysed areas in terms of education quality. This limitation justifies the need to determine a single synthetic measure of education quality, which will incorporate, apart from the indicators of educational value added already mentioned, also the percentage of students passing the matura examination and the numbers of schools having a positive (favourable) or negative (unfavourable) result for educational value added.

\section{Methodology}

The authors adopted the following research scheme, enabling the determination of a synthetic measure of education quality (Hellwig's method):

1) Calculation of a synthetic measure of education quality for the analysed counties;

2) Normalisation of the synthetic measure of education quality using the zero unitarisation method to obtain an indicator in the range $[0 ; 1]$ (this enables the interpretation of changes in \%); 
3) Estimation of a model explaining the variation in the synthetic indicator of quality as a function of selected economic and social determinants.

The above scheme was applied based on data covering both general and vocational high schools. An analysis was conducted of all 310 Polish nonmetropolitan counties in 2013. The definition of a non-metropolitan county, in the current system of administrative division, is not unambiguously formulated, although in economics journalism it is generally taken to include all county-level divisions (powiats) which are not towns or cities having a separate powiat status. The data for the analyses of education quality were obtained from the Ministry of National Education, the Institute of Educational Research (Educational Value Added Group), and the websites of regional examination commissions. Data concerning socioeconomic determinants were obtained from the Local Data Banks of the Polish Central Statistical Office.

\section{Measuring education quality - construction of a synthetic indicator}

A synthetic measure of education quality was determined by Hellwig's method, following the procedure outlined here:

\section{1) Identification of variables making up the measure of education quality}

Table 1. Diagnostic variables for determination of a synthetic measure of education quality

\begin{tabular}{|c|l|c|}
\hline \multicolumn{1}{|c|}{ Code } & \multicolumn{1}{|c|}{ Diagnostic variable } & Influence type \\
\hline \multicolumn{2}{|c|}{ General high schools } \\
\hline \multicolumn{2}{|c|}{} \\
\hline $\mathrm{X}_{1}$ & Matura pass rate & positive \\
\hline $\mathrm{X}_{2}$ & Number of students passing matura & positive \\
\hline $\mathrm{X}_{3}$ & Educational value added in the humanities & positive \\
\hline $\mathrm{X}_{4}$ & Number of schools with positive EVA in the humanities & positive \\
\hline $\mathrm{X}_{5}$ & Number of schools with negative EVA in the humanities & negative \\
\hline $\mathrm{X}_{6}$ & Educational value added in Polish & positive \\
\hline
\end{tabular}




\begin{tabular}{|c|l|c|}
\hline Code & \multicolumn{1}{|c|}{ Diagnostic variable } & Influence type \\
\hline $\mathrm{X}_{7}$ & Number of schools with positive EVA in Polish & positive \\
\hline $\mathrm{X}_{8}$ & Number of schools with negative EVA in Polish & negative \\
\hline $\mathrm{X}_{9}$ & Educational value added in mathematics and science subjects & positive \\
\hline $\mathrm{X}_{10}$ & Number of schools with positive EVA in mathematics and science subjects & positive \\
\hline $\mathrm{X}_{11}$ & $\begin{array}{l}\text { Number of schools with negative EVA in mathematics and science } \\
\text { subjects }\end{array}$ & negative \\
\hline $\mathrm{X}_{12}$ & Educational value added in mathematics & positive \\
\hline $\mathrm{X}_{13}$ & Number of schools with positive EVA in mathematics & positive \\
\hline $\mathrm{X}_{14}$ & Number of schools with negative EVA in mathematics & negative \\
\hline & \multicolumn{1}{|c|}{ Technical high schools } & positive \\
\hline $\mathrm{X}_{15}$ & Matura pass rate & positive \\
\hline $\mathrm{X}_{16}$ & Number of students passing matura & positive \\
\hline $\mathrm{X}_{17}$ & Educational value added in the humanities & positive \\
\hline $\mathrm{X}_{18}$ & Number of schools with positive EVA in the humanities & negative \\
\hline $\mathrm{X}_{19}$ & Number of schools with negative EVA in the humanities & positive \\
\hline $\mathrm{X}_{20}$ & Educational value added in Polish & positive \\
\hline $\mathrm{X}_{21}$ & Number of schools with positive EVA in Polish & negative \\
\hline $\mathrm{X}_{22}$ & Number of schools with negative EVA in Polish & positive \\
\hline $\mathrm{X}_{23}$ & Educational value added in mathematics and science subjects & positive \\
\hline $\mathrm{X}_{24}$ & Number of schools with positive EVA in mathematics and science subjects & positive \\
\hline $\mathrm{X}_{25}$ & $\begin{array}{l}\text { Number of schools with negative EVA in mathematics and science } \\
\text { subjects }\end{array}$ & negative \\
\hline $\mathrm{X}_{26}$ & Educational value added in mathematics & number of schools with positive EVA in mathematics \\
\hline $\mathrm{X}_{27}$ & Number of schools with negative EVA in mathematics \\
\hline $\mathrm{X}_{28}$ & Number \\
\hline
\end{tabular}

Source: based on data from the Polish Ministry of National Education, the Institute of Educational Research (Educational Value Added Group), and websites of regional examination commissions.

Preliminary analysis of the empirical data involved determining a coefficient of variation for each variable. This is a relative measure of dispersion, and enables the elimination of quasi-static variables. The coefficient for the $j$ th variable was calculated using formula (1) (Borkowski, Dudek, Szczęsny 2003: 62):

$$
V_{j}=\frac{S_{j}}{\bar{x}_{j}}
$$


where:

$V_{j}$ is the coefficient of variation for the $j$ th variable;

$S_{j}$ is the standard deviation for the $j$ th variable, computed from formula (2):

$$
S_{j}=\sqrt{n^{n-1} \sum_{i=1}^{n}\left(x_{i j}-\bar{x}\right)^{2}}
$$

$\bar{x}_{j}$ is the arithmetic mean of the $j$ th variable, computed from formula (3):

$$
\bar{x}_{j}=n^{-1} \sum_{i=1}^{n} x_{i j},(i=1, \ldots, n)
$$

Based on the value obtained, the degree of dispersion of the analysed feature was classified as follows:

$0-0.20$ : static

0.21-0.40: moderate dispersion

0.41-0.60: strong dispersion

0.61 or higher: very strong dispersion

The set of analysed variables is reduced by eliminating those for which $\left|V_{j}\right| \leq V$, where $V^{*}$ denotes the critical value of the coefficient of variation. The critical value in the case of the analysed set of variables was taken to be $V^{*}=0.10$.

Standardisation was performed using formula (4) (Gatnar, Walesiak 2004: 124-133):

$$
t_{i j}=\frac{x_{i j}-\bar{x}_{j}}{S_{j}}
$$

where:

$t_{i j}$ is the standardised value of the $j$ th feature in the $i$ th county;

$x_{i j}$ is the empirical value of the $j$ th feature in the $i$ th county;

$\bar{x}$ is the arithmetic mean of the $j$ th feature;

$S_{j}$ is the standard deviation of the $j$ th feature. 
2) Identification of features with positive and negative contribution

A distinction was made between variables making positive and negative contributions to education quality (Table 1 ). The latter type were converted to variables with positive contribution by the application of formula (5):

$$
x_{i j}=\frac{1}{x_{i j}}
$$

\section{3) Determination of development standard}

The matrix of variables following standardisation is used as a basis for determining the development standard, which is an abstract object (county) $\mathrm{P}_{\mathrm{o}}$ with standardised coordinates $\mathrm{z}_{01}, \mathrm{z}_{02}, \ldots, \mathrm{z}_{\mathrm{oj}}$ ' where $z_{o j}=\max \left\{z_{i j}\right\}$ if $z_{j}$ is a variable with a positive contribution, and $z_{\mathrm{oj}}=\min \left\{z_{\mathrm{ij}}\right\}$ if $\mathrm{z}_{\mathrm{j}}$ is a variable with a negative contribution. The development standard thus represents a hypothetical county having the best of the observed values for each of the variables.

\section{4) Computation of the synthetic Hellwig indicator}

At the next step, for each object $\mathrm{P}_{\mathrm{i}}$ (county), the distance from the standard was computed using formula (6):

$$
d_{i}=1-\frac{D_{i 0}}{D_{0}}(i=1,2, \ldots, n)
$$

where:

$D_{i 0}$ is the distance of the $i$ th object from object $\mathrm{P}_{0}$ :

$$
\begin{aligned}
& D_{i 0}=\sqrt{\sum_{j=1}^{m}\left(z_{i j}-z_{o j}\right)^{2}} \\
& \bar{D}_{0}=n^{-1} \sum_{i=1}^{n} D_{i 0}
\end{aligned}
$$




$$
\begin{aligned}
& S_{0}=\sqrt{n^{-1} \sum_{i=1}^{n}\left(D_{i 0}-\bar{D}_{0}\right)^{2}} \\
& D_{0}=\bar{D}_{0}+2 S_{0}
\end{aligned}
$$

\section{5) Normalisation of the synthetic Hellwig indicator}

The results obtained in stage 5 (synthetic Hellwig indicator) were normalised by the zero unitarisation method according to formula (11):

$$
q_{i}=\frac{d_{i}-\min _{d_{i}}}{\max _{d_{i}}-\min _{d_{i}}}
$$

6) Classification of counties according to the normalised Hellwig taxonomic measure

The counties were divided into four quartiles according to quality as expressed by the synthetic Hellwig measure.

\section{Selection of explanatory variables}

Exogenic variables explaining the social and economic determinants were identified with reference to literature reports on the subject of education quality, particularly the education production function. The following were taken as social determinants of education quality:

- crime rate $\mathrm{v}_{1}$ (Lochner, Moretti 2004: 155-189);

- divorce rate $\mathrm{v}_{2}$ (Coleman et al. 1966; Badr, Morrissey, Appleton 2003: $1-38)$

- net migration $\mathrm{v}_{3}$;

- proportion of graduates in the population $\mathrm{v}_{4}$;

- proportion of people with high school education $\mathrm{v}_{5}$ (Jakubowski 2007: 85-105; Badr et al. 2003: 1-38);

- number of library books $\mathrm{v}_{6}$;

- number of interest clubs $\mathrm{v}_{7}$; 
- index of membership of interest clubs $\mathrm{v}_{8}$;

- borrowings from libraries $\mathrm{v}_{9}$;

- events run by culture centres $\mathrm{v}_{10}$ (Schneeweis, Winter-Ebmer 2005: 387-409).

The following were taken as economic determinants of education quality: number of pupils $\mathrm{v}_{11}$ (Chakraborty 2009: 1-18; Afonso, Aubyn 2004: 227 246; Ismail, Cheng 2005: 1-8);

- expenditure incurred on contract, nominated and certified teachers $\mathrm{v}_{12}-\mathrm{v}_{14}$ (Kremer 1995: 247-254; Pritchett, Filmer 1999: 223-239; Darling-Hammond 1999: 166-173);

- average monthly gross salary in the county $\mathrm{v}_{15}$ (Barro, Lee 2001: 465488; Hanushek, Luque 2002: 1-42);

- unemployment rate $\mathrm{v}_{16}$;

- children whose parents receive child benefit $\mathrm{v}_{17}$;

- home floor space $\mathrm{v}_{18}$;

- number of recipients of housing benefit $\mathrm{v}_{19}$ (Badr et al. 2003: 1-38; Chakraborty 2009: 1-18).

Since the influence of exogenic factors on education quality may be of a multi-level (hierarchic) nature, the analysis took into account the provincial (województwo) level through the introduction of dummy variables to address the range of variation in education quality not observable at county level.

Method of computing the production function

It was assumed that the regression model for education quality in a total population of 310 elements (counties) takes a linear form, where for each observation $i$ there is a linear relationship between the output variable $q_{\mathrm{i}}$ (the synthetic indicator) and $K$ explanatory exogenic variables $v_{1}, v_{2}, v_{3}, \ldots, v_{K}$ from the defined set of 19 potential socioeconomic variables:

$$
q_{i}=\beta_{0}+\beta_{1} v_{1 i}+\beta_{2} v_{2 i}+\cdots+\beta_{K} v_{K i}+\varepsilon_{i}
$$

$i=0,1,2,3, \ldots, 310$

$k=1, \ldots, K$

$\varepsilon_{\mathrm{i}}=$ random component

The variables $q_{\mathrm{i}}$ and $v_{1}, v_{2}, v_{3}, \ldots, v_{k}$ represent very detailed cross-sectional data exposing the diversity of the analysed counties, which results from wide-ranging historical, geographical, demographic and cultural factors. 
This diversity results in the heteroscedasticity of the disturbances $\varepsilon_{\mathrm{i}}$, which means that these disturbances are not dispersed uniformly about the zero expected value and, thus, their variance is not uniform. Although in the case of the whole population the random component does not matter, we must take into consideration that the population of rural counties varies to some extent from year to year. Thus, in order to apply the results to the subsequent years, one cannot ignore the heteroscedasticity of the random component. For this reason, the parameters were calculated using a generalised least squares method (Górecki 2010: 109-133). Because the analysis covered the entire population, statistical significance does not play a role here. Therefore, the selection of explanatory variables was based on the criterion of collinearity of independent variables, so that the coefficient of tolerance for each explanatory variable was greater than 0.2 (the lower the tolerance, the smaller the variable's contribution to the model, in view of its relationships with other explanatory variables). This is significantly more rigorous than the criterion generally applied in sociological research, where the acceptable tolerance is defined as 0.1 (Shah, Bhatti 2012: 503). The above procedure led to a reduction in the set of exogenic variables in the model. The final set is listed in Table 2, and also provided a basis on which to eliminate the dummy variables, which not only reduced the quality of fit of the model, but also exhibited low tolerance.

\section{Results}

\section{Taxonomic analysis of education quality}

The classification of non-metropolitan counties in Poland into quartiles based on the synthetic indicator of education quality $\left(q_{i}\right)$ is shown on the map in Figure 1. This suggests two conclusions concerning the geographical variation in education quality in rural areas in Poland:

1) On the onehand, the "centre-peripheryaxis" is seen to be of significance in the zones of influence of large conurbations. In the subject literature, this criterion is considered key to the systematisation of rural areas in terms of structures of socioeconomic development (Stanny 2013: 207-208). Similarly in this case, the average education quality in counties in the upper quartile (A), concentrated around 
the largest conurbations (Warsaw, Poznań, Kraków, Wrocław, Gdańsk), is almost twice the level of quartile $\mathrm{C}$ and almost three times that of quartile $\mathrm{D}$ (cf. Table 2). This may be an indication of the migration of young people with the highest educational potential in the direction of those large conurbations.

2) On the other hand, the impact of the centre-periphery axis is not found everywhere in Poland. Non-metropolitan counties with education quality values in the lower quartiles $(\mathrm{C}, \mathrm{D})$ can be found in the vicinity of most medium-sized towns (cf. Fig. 1). This suggests the need to seek other mechanisms for the geographical variation found in education quality, not related to the centre-periphery continuum. The authors have concluded that more applicable in this case may be gravitation models, used, for instance, in the analysis of trade flows between countries (Pietrzak 2010: 79-98; Kalirajan 2010: 185-193; Egger 2002: 297-312; Roberts 2004: 335-353) or to explain geographical variation in agricultural land value (Guiling, Brorsen, Doye 2009: 252-264; Shi, Phipps, Colyer 1997: 90-100; Nickerson et al. 2012).

In the analysis of international flows of goods, the gravitation model was first used by a Dutch economist (Tinbergen 1962). In that model, alluding to Newton's universal law of gravitation, the flow of trade between countries varied in direct proportion to the GNP of the countries in question and in inverse proportion to the distance between them. A key issue in gravitation models is the definition of an output variable that describes some aspect of the interaction of the analysed structures. In the case of education this may be the influx of students and/or teachers with high educational potential, which has a direct impact on educational results. The explanatory variables correspond to the factors which shape that potential. We recall that the purpose of this study is to identify such factors, an issue to which we shall return in the following section. 
Table 2. Average values of the output variable $q$ and the variables explaining education quality in rural areas $v$ in quartile groups

\begin{tabular}{|c|c|c|c|c|c|c|c|}
\hline \multirow{2}{*}{ Class } & \multirow{2}{*}{$\mathrm{N}$} & \multicolumn{6}{|c|}{ Variable } \\
\hline & & $\mathrm{v}_{1}$ & $\mathrm{v}_{2}$ & $\mathrm{v}_{3}$ & $\mathrm{v}_{4}$ & $\mathrm{v}_{5}$ & $\mathrm{v}_{6}$ \\
\hline A & 77 & $\downarrow 90.78$ & $\downarrow 1040.16$ & $\downarrow 2062.98$ & $\uparrow 3560.81$ & 2.28 & 1.49 \\
\hline B & 78 & 98.60 & 1097.64 & 2090.16 & 2472.55 & $\uparrow 2.39$ & 1.45 \\
\hline $\mathrm{C}$ & 77 & 109.09 & 1173.35 & 2185.06 & 1808.20 & 2.30 & $\uparrow 1.51$ \\
\hline $\mathrm{D}$ & 78 & $\uparrow 123.49$ & $\uparrow 1355.18$ & $\uparrow 2304.97$ & $\downarrow 1878.29$ & $\downarrow 2.20$ & $\downarrow 1.44$ \\
\hline Total & 310 & 105.53 & 1166.97 & 2161.03 & 2428.32 & 2.29 & 1.47 \\
\hline & & $v_{7}$ & $\mathrm{v}_{8}$ & $\mathrm{v}_{9}$ & $\mathrm{v}_{10}$ & $\mathrm{v}_{11}$ & $\mathrm{v}_{12}$ \\
\hline A & 77 & $\uparrow-0.39$ & $\uparrow 3281.63$ & $\downarrow 7.42$ & $\downarrow 9.20$ & $\uparrow 11.23$ & $\uparrow 26.13$ \\
\hline $\mathrm{B}$ & 78 & $\downarrow-0.73$ & 3205.63 & $\uparrow 8.11$ & 9.88 & 10.26 & 25.17 \\
\hline $\mathrm{C}$ & 77 & -0.70 & 3208.60 & 7.84 & 10.45 & 10.16 & $\downarrow 24.73$ \\
\hline $\mathrm{D}$ & 78 & -0.51 & $\downarrow 3163.46$ & 7.98 & $\uparrow 10.72$ & $\downarrow 10.03$ & 24.95 \\
\hline Total & 310 & -0.58 & 3214.64 & 7.84 & 10.06 & 10.42 & 25.24 \\
\hline & & $\mathrm{v}_{13}$ & $\mathrm{v}_{14}$ & $\mathrm{v}_{15}$ & $\mathrm{v}_{16}$ & $\mathrm{v}_{17}$ & $\mathrm{v}_{18}$ \\
\hline A & 77 & $\downarrow 3470.47$ & $\downarrow 10.705$ & 26.28 & $\downarrow 9.54$ & $\downarrow 18.65$ & $\downarrow 53.58$ \\
\hline $\mathrm{B}$ & 78 & 3563.92 & 10.708 & $\downarrow 25.77$ & 10.86 & 19.21 & 119.59 \\
\hline $\mathrm{C}$ & 77 & $\uparrow 3951.08$ & 10.765 & 25.90 & $\uparrow 12.04$ & $\uparrow 20.15$ & 161.38 \\
\hline $\mathrm{D}$ & 78 & 3661.73 & $\uparrow 10.779$ & $\uparrow 26.48$ & 10.46 & 19.71 & $\uparrow 332.61$ \\
\hline Total & 310 & 3661.48 & 10.739 & 26.11 & 10.72 & 19.43 & 167.17 \\
\hline & & $\mathrm{v}_{19}$ & $\begin{array}{l}\text { Synthetic } \\
\text { indicator } \\
\text { of educa- } \\
\text { tion quality }\end{array}$ & & & & \\
\hline A & 77 & $\downarrow 0.466$ & $\uparrow 0.561424$ & & & & \\
\hline B & 78 & 0.468 & 0.405321 & & & & \\
\hline $\mathrm{C}$ & 77 & $\uparrow 0.508$ & 0.337080 & & & & \\
\hline $\mathrm{D}$ & 78 & 0.499 & $\downarrow 0.238637$ & & & & \\
\hline Total & 310 & 0.485 & 0.385205 & & & & \\
\hline
\end{tabular}

${ }^{*} \mathrm{v}_{1}$ - expenditure on contract teachers' salaries; $\mathrm{v}_{2}$ - expenditure on nominated teachers' salaries; $\mathrm{v}_{3}$ - expenditure on certified teachers' salaries; $\mathrm{v}_{4}-$ number of pupils; $\mathrm{v}_{5}-$ crimes confirmed in completed preparatory proceedings; $\mathrm{v}_{6}-$ divorces; $\mathrm{v}_{7}-$ net foreign migration; $\mathrm{v}_{8}-$ average gross monthly salary; $\mathrm{v}_{9}$ - children whose parents receive child benefit; $\mathrm{v}_{10}$ - registered unemployed as proportion of population of working age; $\mathrm{v}_{11}$ - graduates as proportion of the population; $\mathrm{v}_{12}$ - proportion of the population with high school education; $\mathrm{v}_{13}$ - library book numbers per 1000 persons; $\mathrm{v}_{14}$ - members of interest clubs at culture centres per 1000 persons; $\mathrm{v}_{15}$ - average home floor space per person; $\mathrm{v}_{16}$ - number of recipients of housing benefit; $\mathrm{v}_{17}$ library borrowings per reader; $\mathrm{v}_{18}$ - events run by culture centres; $\mathrm{v}_{19}$ - interest clubs operating at culture centres

Source: based on the analysed data. 
1 Figure 1. Classification of non-metropolitan counties by education quality

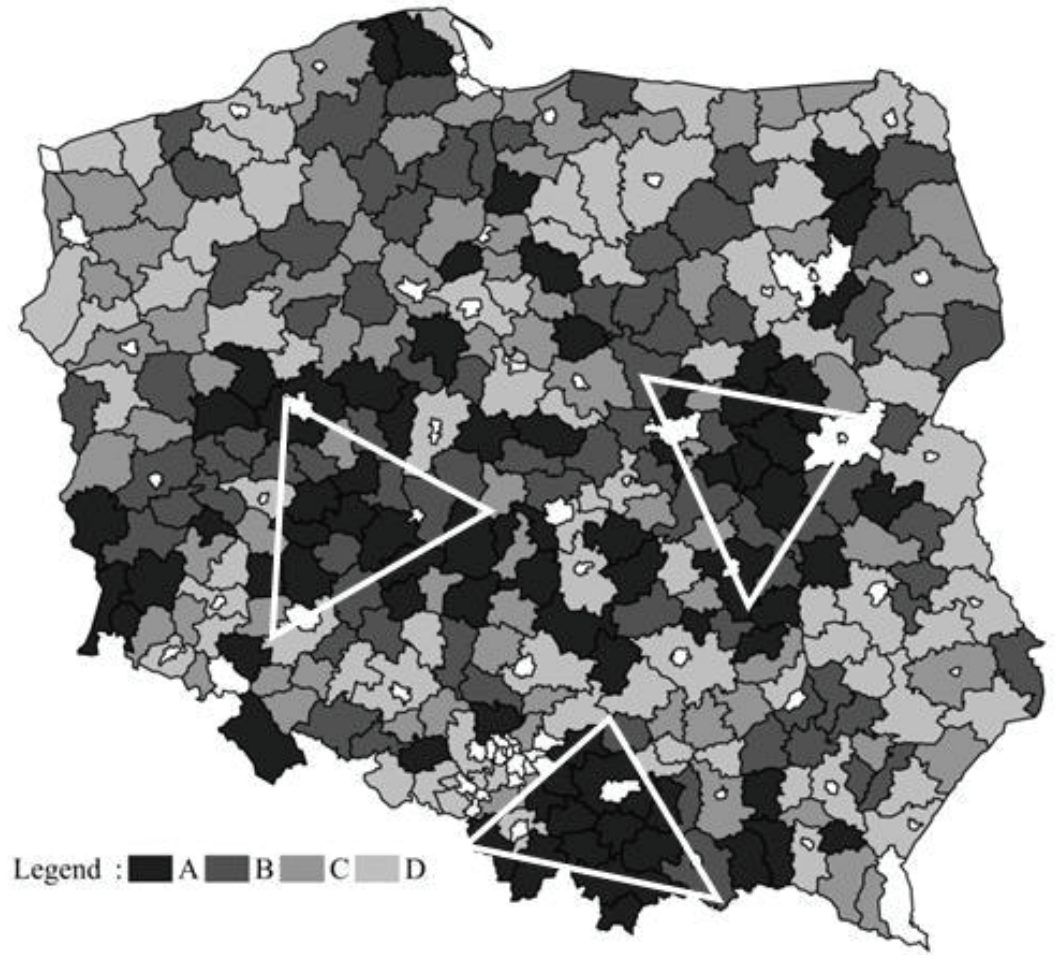

Source: based on the analysed data.

The map in Fig. 1 suggests that in Poland, gravitational influence on the aforementioned potential is exerted primarily by the three areas marked with white triangles. Thus, apart from socioeconomic determinants, educational potential is also affected by a location factor. It is interesting to note that the attraction of that potential is not of a pointwise nature. We may note that the counties in the upper quartiles of education quality are not distributed concentrically around the listed conurbations, but are arranged asymmetrically with respect to them, "gravitating" in a specific direction (for instance, to the south-east in the case of Warsaw, and the south-west in the case of Kraków). We therefore appear to have three gravitational systems: Poznań-Wrocław-Kalisz, Warsaw-Radom-Siedlce, and Kraków-Nowy Sącz-Bielsko-Biała (these cities either are present provincial capitals or had such a status before the administrative reform of 1999). The theoretical form 
of the gravitation model describing the influx of human capital (with high educational potential) to region $i$ may thus be as follows:

$$
H c=\frac{\left(v_{1}+v_{2}+\cdots+v_{k}\right)^{\alpha}}{\left(D I S T_{A}+D I S T_{B}+D I S T_{C}\right)^{\beta}}
$$

where:

$H c$ denotes the influx of human capital; $v_{1}+v_{2}+\cdots+v_{k}$ are defined as in equation (12); A, B, C denote metropolitan centres.

The first step, then, is to compute the function $=\mathrm{f}\left(v_{\mathrm{ki}}\right)$. Estimation of the above gravitation model goes beyond the scope of the present work, but it would appear to have practical justification from the point of view both of the selection of an appropriate set of variables $v_{\mathrm{ki}}$ and of the location factor. This may therefore form the subject of a further stage of research. The same is indicated by results (Czapiński, Panek 2013) relating to the taxonomic analysis of quality of life in Poland, described by means of a "local index of social development". This indicator was found to attain its highest values within the same gravitational systems as does the indicator of education quality in the present work (cf. Fig. 2). The construction of the social development index involved three dimensions: wealth (residents' average level of wealth), education (percentage of children in pre-school education, middle school examination results), and health (life expectancy at birth, aggregated rate of deaths from cancer and cardiovascular diseases). The set of variables indicated in the present work as explaining education quality in rural areas overlaps in a qualitative sense with the first and second dimensions of the social development index, although its construction is significantly more extensive. 
Figure 2. Local index of social development

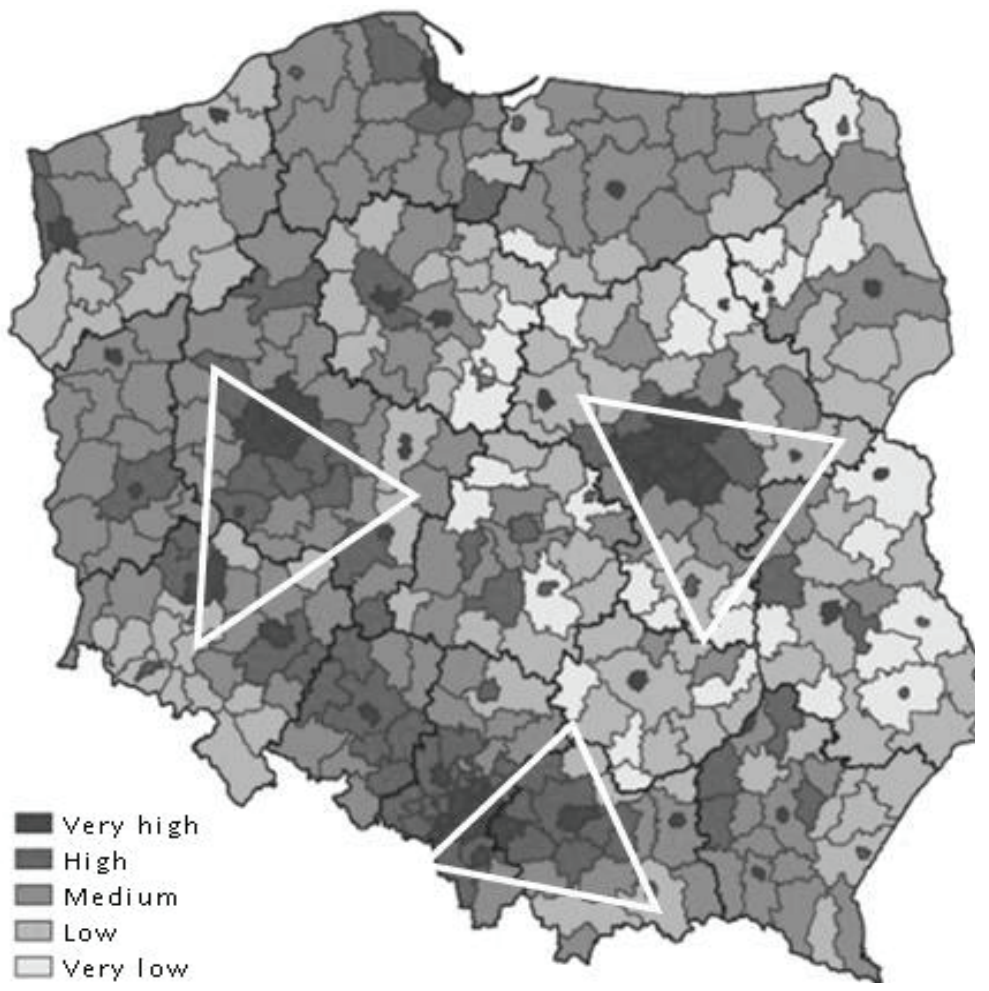

Source: Czapiński and Panek (2013: 13).

It may therefore be assumed that if quality of life (according to the social development index) and education quality reach their highest values in similar locations in Poland, there exists a positive functional link between those categories.

The cited report of Czapiński and Panak (2013) does not give an unambiguous answer to the question of what are the social and economic determinants of education quality, since, firstly, it defines such quality in very simplified terms (based on the result of a single middle school exam in mathematics and science subjects), secondly, the coefficients of determination in the computed relationships between education and other variables are relatively low $\left(\mathrm{R}^{2}\right.$ not greater than 0.5$)$, and, thirdly, it fails to model education quality in a multidimensional fashion. Nonetheless, the partial results given there provide a good outline of the research problem: 
is education quality in rural areas determined by strictly economic factors? In other words, to what extent is a rise in income a necessary variable, and to what extent a sufficient one, for improvement in education quality in Poland, particularly in the quality of education funded by non-metropolitan counties?

\section{Regression model}

Sociologists question the claim that economic variables are a key factor for education quality in rural areas (in the sense of results attained and EVA) (Gmerek 2010: 39-67). Domalewski (2005:73) attaches great importance to the growth in educational aspirations that is particularly visible among young people living in rural areas and coming from less urbanised backgrounds. Awareness of the importance of education in a market economy is becoming more and more widespread, an effect of which is the equalisation of levels of educational competence of young people from different environments. The cited author writes that "the times when place of residence was a factor clearly differentiating pupils in terms of cultural and educational capital are a thing of the past". In the aforementioned report (Czapiński, Panak 2013), which covered all counties (including metropolitan ones), the relationship between the education index and GDP per capita in provinces was described by $\mathrm{R}^{2}=0.42$, and that between the education index and employment income per capita in counties by $\mathrm{R}^{2}=0.5$. It should beremembered, however, that theeducation index used in that report took into account the percentage of children in pre-school education alongside the results of the middle school examination. The relationship between the education index and the results of the mathematics and science part of the examination had a coefficient of determination of only 0.25 . It is thus difficult to state, on the basis of these single-dimensional dependencies, what is the relative importance of economic factors for education quality. However, the model developed in the present work indicates that economic factors are indeed of key importance, as regards both personal income and the system of school funding. 
Table 3. Results of estimation of a linear model for education quality in rural areas (model with coefficient of determination for the entire population $\mathrm{R}^{2}=0.890595$, corrected $\mathrm{R}^{2}=0.883427$ )

\begin{tabular}{|c|c|c|c|c|c|}
\hline $\begin{array}{c}\text { Variable } \\
\text { classification }\end{array}$ & $\begin{array}{l}\text { Variables v } \\
\text { in model }\end{array}$ & Parameter $\beta$ & $\beta$ in $\%$ & $\begin{array}{l}\text { Standard } \\
\text { error }\end{array}$ & $\begin{array}{c}\beta \text { for standardised } \\
\text { explanatory } \\
\text { variables }\end{array}$ \\
\hline & constant & 0.233156 & & 0.131667 & \\
\hline \multirow[t]{4}{*}{$\begin{array}{l}\text { 1. SCHOOL } \\
\text { FUNDING }\end{array}$} & $\begin{array}{l}\text { Expenditure } \\
\text { on contract } \\
\text { teachers }\end{array}$ & $2.30863 \mathrm{e}-05$ & $0.002 \%$ & $3.67569 \mathrm{e}-05$ & $0.25 \%$ \\
\hline & $\begin{array}{l}\text { Expenditure } \\
\text { on certified } \\
\text { teachers }\end{array}$ & $-2.40979 \mathrm{e}-05$ & $-0.002 \%$ & $8.37688 \mathrm{e}-06$ & $-1.51 \%$ \\
\hline & $\begin{array}{l}\text { Expenditure } \\
\text { on nominated } \\
\text { teachers }\end{array}$ & $-8.80358 \mathrm{e}-06$ & $-0.001 \%$ & $1.0912 \mathrm{e}-05$ & $-0.47 \%$ \\
\hline & Number of pupils & $4.17707 \mathrm{e}-05$ & $0.004 \%$ & $5.02449 \mathrm{e}-06$ & $5.79 \%$ \\
\hline \multirow{3}{*}{$\begin{array}{l}\text { 2. SOCIO- } \\
\text { DEMOGRAPHIC }\end{array}$} & Crime rate & -0.000273033 & $-0.027 \%$ & 0.00731291 & $-0.02 \%$ \\
\hline & Divorce rate & -0.0143869 & $-1.439 \%$ & 0.0174688 & $-0.60 \%$ \\
\hline & Net migration & 0.000234779 & $0.023 \%$ & 0.00358747 & $0.05 \%$ \\
\hline \multirow[t]{3}{*}{ 3. INCOME } & Monthly salaries & $2.95143 \mathrm{e}-05$ & $0.003 \%$ & $2.00358 \mathrm{e}-05$ & $1.15 \%$ \\
\hline & $\begin{array}{l}\text { Child benefit } \\
\text { take-up rate }\end{array}$ & 0.00139606 & $0.140 \%$ & 0.00331952 & $0.33 \%$ \\
\hline & Unemployment & -0.000354759 & $-0.035 \%$ & 0.00169271 & $-0.12 \%$ \\
\hline \multirow{4}{*}{$\begin{array}{l}\text { 4. LEVEL OF } \\
\text { EDUCATION }\end{array}$} & Graduates & 0.00201636 & $0.202 \%$ & 0.00405582 & $0.48 \%$ \\
\hline & $\begin{array}{l}\text { High school } \\
\text { education }\end{array}$ & 0.00312132 & $0.312 \%$ & 0.00272596 & $0.91 \%$ \\
\hline & Library books & $1.34334 \mathrm{e}-05$ & $0.001 \%$ & $5.91784 \mathrm{e}-06$ & $1.20 \%$ \\
\hline & $\begin{array}{l}\text { Members } \\
\text { of interest clubs }\end{array}$ & 0.0012155 & $0.122 \%$ & 0.000751444 & $0.70 \%$ \\
\hline \multirow{2}{*}{$\begin{array}{l}\text { 5. CONDITIONS } \\
\text { OF ACCOMMO- } \\
\text { DATION }\end{array}$} & Home floor space & -0.00111293 & $-0.111 \%$ & 0.00218098 & $-0.31 \%$ \\
\hline & $\begin{array}{l}\text { Housing benefit } \\
\text { rate }\end{array}$ & -0.000432851 & $-0.043 \%$ & 0.00100667 & $-0.29 \%$ \\
\hline \multirow[t]{3}{*}{ 6. RECREATION } & $\begin{array}{l}\text { Library } \\
\text { borrowings }\end{array}$ & -0.00431572 & $-0.432 \%$ & 0.0018965 & $-1.38 \%$ \\
\hline & $\begin{array}{l}\text { Culture centre } \\
\text { events }\end{array}$ & -0.00100113 & $-0.100 \%$ & 0.00155011 & $-0.37 \%$ \\
\hline & Interest clubs & -0.0170286 & $-1.703 \%$ & 0.00902069 & $-0.51 \%$ \\
\hline
\end{tabular}

Source: computed using GRETL and STATISTICA 12 software. 
Table 3 shows the values of the parameter $\beta$ in the model computed for the various explanatory variables $v$. The final column contains standardised $\beta$ values, which are additive and enable comparison of the strength of influence of the variables $v$ and also of the combined areas 1-6 (cf. Table 3) on $q$ (the synthetic index of education quality). The variables are grouped in six areas; in the final column it is possible to sum the absolute values of $\beta$ for these areas. This shows that the greatest influence (positive on balance) on education quality is exerted by economic variables, namely the sum of the areas "school funding" and "income", followed by "level of education" (again having a positive influence) and then "recreation" (paradoxically having a negative influence). The lowest standardised $\beta$ values are found for the areas titled "socio-demographic" and "conditions of accommodation".

Separate commentary is necessary concerning the identified directions of influence on education quality exerted by the explanatory variables. Relevant interpretations for all $\beta$ values are contained in Table 4 .

Table 4. Interpretation of the parameters of the model of education quality in rural areas

\begin{tabular}{|c|c|c|c|}
\hline No. & Variable & Unit & Influence \\
\hline 1. & $\begin{array}{l}\text { Expenditure on salaries } \\
\text { of contract teachers }\end{array}$ & $\begin{array}{l}\text { amount per } \\
\text { pupil }\end{array}$ & $\begin{array}{l}\text { An increase in expenditure on salaries } \\
\text { of contract teachers by } 100 \text { PLN causes } \\
\text { a } 0.2 \% \text { increase in the education quality index }\end{array}$ \\
\hline 2. & $\begin{array}{l}\text { Expenditure on salaries } \\
\text { of nominated teachers }\end{array}$ & $\begin{array}{l}\text { amount per } \\
\text { pupil }\end{array}$ & $\begin{array}{l}\text { An increase in expenditure on salaries } \\
\text { of nominated teachers by } 100 \text { PLN causes } \\
\text { a } 0.088 \% \text { decrease in the education quality } \\
\text { index }\end{array}$ \\
\hline 3. & $\begin{array}{l}\text { Expenditure on salaries } \\
\text { of certified teachers }\end{array}$ & $\begin{array}{l}\text { amount per } \\
\text { pupil }\end{array}$ & $\begin{array}{l}\text { An increase in expenditure on salaries } \\
\text { of certified teachers by } 100 \text { PLN causes } \\
\text { a } 0.2 \% \text { decrease in the education quality } \\
\text { index }\end{array}$ \\
\hline 4. & Number of pupils & $\begin{array}{c}\text { number } \\
\text { of pupils } \\
\text { in the county }\end{array}$ & $\begin{array}{l}\text { An increase in the number of pupils in the } \\
\text { county by } 100 \text { causes a } 0.4 \% \text { increase in the } \\
\text { education quality index }\end{array}$ \\
\hline 5. & $\begin{array}{l}\text { Crimes confirmed by } \\
\text { completed preparatory } \\
\text { proceedings }\end{array}$ & $\begin{array}{l}\text { per } 100 \\
\text { persons }\end{array}$ & $\begin{array}{l}\text { An increase in the crime rate by } 10 \text { per } \\
100 \text { persons causes a } 0.27 \% \text { decrease in the } \\
\text { education quality index }\end{array}$ \\
\hline 6. & Divorces & $\begin{array}{l}\text { per } 1000 \\
\text { residents }\end{array}$ & $\begin{array}{l}\text { An increase in the divorce rate by } 10 \text { per } \\
1000 \text { residents causes a } 14.4 \% \text { decrease } \\
\text { in the education quality index }\end{array}$ \\
\hline
\end{tabular}




\begin{tabular}{|c|c|c|c|}
\hline 7. & Net foreign migration & $\begin{array}{l}\text { per } 1000 \\
\text { residents }\end{array}$ & $\begin{array}{l}\text { An increase in net migration (incoming } \\
\text { minus outgoing residents) by } 10 \text { per } 1000 \\
\text { residents causes a } 0.23 \% \text { increase in the } \\
\text { education quality index }\end{array}$ \\
\hline 8. & Average gross monthly salary & PLN & $\begin{array}{l}\text { An increase in the average gross monthly } \\
\text { salary by } 1000 \text { PLN causes a } 2.95 \% \text { increase } \\
\text { in the education quality index }\end{array}$ \\
\hline 9. & $\begin{array}{l}\text { Children whose parents } \\
\text { receive child benefit }\end{array}$ & $\begin{array}{l}\% \text { of total } \\
\text { population }\end{array}$ & $\begin{array}{l}\text { A rise in the indicator of children whose } \\
\text { parents receive child benefit by } 10 \text { causes } \\
\text { a } 1.4 \% \text { increase in the education quality index }\end{array}$ \\
\hline 10. & $\begin{array}{l}\text { Registered unemployed as } \\
\text { a proportion of the working- } \\
\text { age population }\end{array}$ & $\%$ & $\begin{array}{l}\text { An increase in the number of unemployed as } \\
\text { a percentage of the working-age population } \\
\text { by } 5 \% \text { causes a } 0.18 \% \text { decrease in the } \\
\text { education quality index }\end{array}$ \\
\hline 11. & $\begin{array}{l}\text { Graduates as percentage } \\
\text { of the population }\end{array}$ & $\%$ & $\begin{array}{l}\text { An increase in the number of graduates as } \\
\text { a percentage of the population causes a } 2 \% \\
\text { increase in the education quality index }\end{array}$ \\
\hline 12. & $\begin{array}{l}\text { Percentage of population } \\
\text { with high school education }\end{array}$ & $\%$ & $\begin{array}{l}\text { An increase in the percentage of the } \\
\text { population with high school education by } \\
10 \% \text { causes a } 3 \% \text { increase in the education } \\
\text { quality index }\end{array}$ \\
\hline 13. & $\begin{array}{l}\text { Library books per } 1000 \\
\text { persons }\end{array}$ & no. of items & $\begin{array}{l}\text { An increase in the number of library books } \\
\text { by } 1000 \text { per } 1000 \text { population causes a } 1.3 \% \\
\text { increase in the education quality index }\end{array}$ \\
\hline 14. & $\begin{array}{l}\text { Members of interest clubs } \\
\text { at culture centres, per } 1000 \\
\text { persons }\end{array}$ & $\begin{array}{l}\text { no. } \\
\text { of persons }\end{array}$ & $\begin{array}{l}\text { An increase in the number of members } \\
\text { of interest clubs by } 10 \text { per } 1000 \text { population } \\
\text { causes a } 1.22 \% \text { increase in the education } \\
\text { quality index }\end{array}$ \\
\hline 15. & $\begin{array}{l}\text { Average home floor space per } \\
\text { person }\end{array}$ & $\mathrm{m}^{2}$ & $\begin{array}{l}\text { An increase in the average home floor space } \\
\text { per person causes a } 0.1 \% \text { decrease in the } \\
\text { education quality index }\end{array}$ \\
\hline 16. & Housing benefit take-up & $\begin{array}{l}\text { ratio to total } \\
\text { population }\end{array}$ & $\begin{array}{l}\text { An increase in housing benefit take-up causes } \\
\text { a } 0.4 \% \text { decrease in the education quality } \\
\text { index }\end{array}$ \\
\hline 17. & Book borrowings per reader & no. of books & $\begin{array}{l}\text { An increase in book borrowings by } 1 \\
\text { per reader causes a } 0.4 \% \text { decrease in the } \\
\text { education quality index }\end{array}$ \\
\hline 18. & Events run by culture centres & $\begin{array}{l}\text { per } 1000 \\
\text { persons }\end{array}$ & $\begin{array}{l}\text { An increase in events run by culture centres } \\
\text { by } 1 \text { per } 1000 \text { population causes a } 0.1 \% \\
\text { decrease in the education quality index }\end{array}$ \\
\hline 19. & $\begin{array}{l}\text { Interest clubs at culture } \\
\text { centres }\end{array}$ & $\begin{array}{l}\text { per } 1000 \\
\text { persons }\end{array}$ & $\begin{array}{l}\text { An increase in the number of interest } \\
\text { clubs at culture centres by } 1 \text { per } 1000 \\
\text { population causes a } 1.7 \% \text { decrease in the } \\
\text { education quality index }\end{array}$ \\
\hline
\end{tabular}

Source: based on Table 3. 
The above interpretations lead to the following conclusions (the most interesting relationships are shown in bold in Table 4):

1) A key factor in the long-term improvement of education quality appears to be the maintenance of a constant rate of increase in national income, since an increase in the average monthly gross salary by 1000 zloty (PLN) brings about an increase by approximately $3 \%$ in the education index. This relationship is also confirmed by scientific reports concerning the impact of society's economic situation on educational results (Rupasingha et al. 2002: 139155; Jakubowski 2007: 85-105). Taking into account also the signs associated with the "crime rate" variable, this provides confirmation of Bourdieu and Passerson's sociological theory of class reproduction in the Polish educational system, which, through unintentional "income selection", appears to reproduce social structures in rural areas (Bourdieu 1994; Passerson 1986; Bourdieu, Passerson 2006). Nonetheless, the modelling results for the "living conditions" area contradict such a mechanism. The problem reduces to the question of whether the rising educational aspirations of young people in rural areas are a force strong enough to break the inertia of the Polish educational system, which, in spite of the reforms of the 1990s, still fails to fulfil the requirements of egalitarianism.

2) Equally important in this regard is the percentage of people with high school education. This phenomenon was noted indirectly by Domalewski and Mikiewicz (2004, chapter 3), who wrote about the ineffectiveness of the educational reforms of the 1990s in terms of fulfilment of the requirements of egalitarianism in education. The creation of separate middle schools, the more widespread provision of general programmes of education at high school level, and the introduction of a system of external examinations at every level of education were intended to weaken the social selectiveness of schooling above middle school level. The analyses of the cited authors show that, in spite of the reform of the education system, schools above middle school level are still selective, and the general and technical high schools are not equally accessible to all, even though it is essentially only high school education and college education that translate into development of human capital. According to those authors, vocational schools continue to attract 
young people from the lowest social strata, and the more limited teaching programme and social environment of those schools add to the social marginalisation of the students learning there.

3) Family breakups have a highly negative effect on education quality. An increase in the divorce rate by 10 per 1000 residents causes the indicator of education quality to fall by as much as $14.4 \%$. This is a cause for concern, given the rapidly growing proportion of broken families in Poland, including in rural areas. This phenomenon is confirmed by foreign literature reports (Kipkorir, Reuben 2015: 792-796).

4) Interestingly, it was found that an increase in the number of pupils in a county by 100 causes the education quality index to increase by $0.4 \%$. The number of pupils in the county determines the size of classes and the number of teachers. The greater availability of teachers with different specialisations proves to be more beneficial to the teaching process than smaller classes where the teacher has to be competent in all areas. The latter situation is characteristic of rural areas, and in large conurbations the direction of influence of this variable would undoubtedly be reversed. This indicator should be interpreted with caution, however, in view of the numerous factors that determine school class sizes. In the literature, a greater and positive significance is often ascribed to smaller classes (Cooper, Cohn 1997: 313-327).

5) The computed education quality model shows that an increase in the salaries of contract teachers may lead to an increase in education quality. This is a justified conclusion in view of the fact that the length of service of contract teachers is usually between 1 and 4 years, and research into teachers' effectiveness indicates that a teacher achieves full capabilities between the third and fifth years of employment (Murnane, Philips 1981: 453-465; Darling-Hammond 1999: 166173). An increase in the salaries of higher-grade teachers causes a drop in education quality. This relationship, although it requires further analysis, may indicate a need to modify the system of teachers' remuneration so as to increase its effectiveness.

6) Somewhat surprising is the negative influence ascribed to all explanatory variables in the area of recreation, e.g. the finding that an increase in book borrowings brings about a decrease in education quality. This may indicate that the works of fiction being borrowed 
have low educational value, taking readers' time without enabling their development. A similar interpretation may be given for the effect of local events and interest clubs, which may be assumed to function in rural areas at the cost of school learning. This relationship undoubtedly requires more detailed research. Negative effects are also found in the case of variables relating to accommodation (home floor space and housing benefit take-up), which indicates that these are not key factors for educational results.

Conclusions regarding the explanatory power of the constructed model may be drawn not only on the basis of the high $\mathrm{R}^{2}$ value, but also by residual analysis. Although in a case where the entire population is considered the normality of the residual distribution and other assumptions of the least squares method are not of great significance, it is beneficial to evaluate characteristics of the deviation of theoretical and empirical values of the model in relation to the range in which the synthetic measure of education quality lies.

Figure 3. Frequency distribution for residuals of the model (observations 1-310, number of intervals $=17$, mean $=-0.000176086$, standard deviation $=0.114444$ )

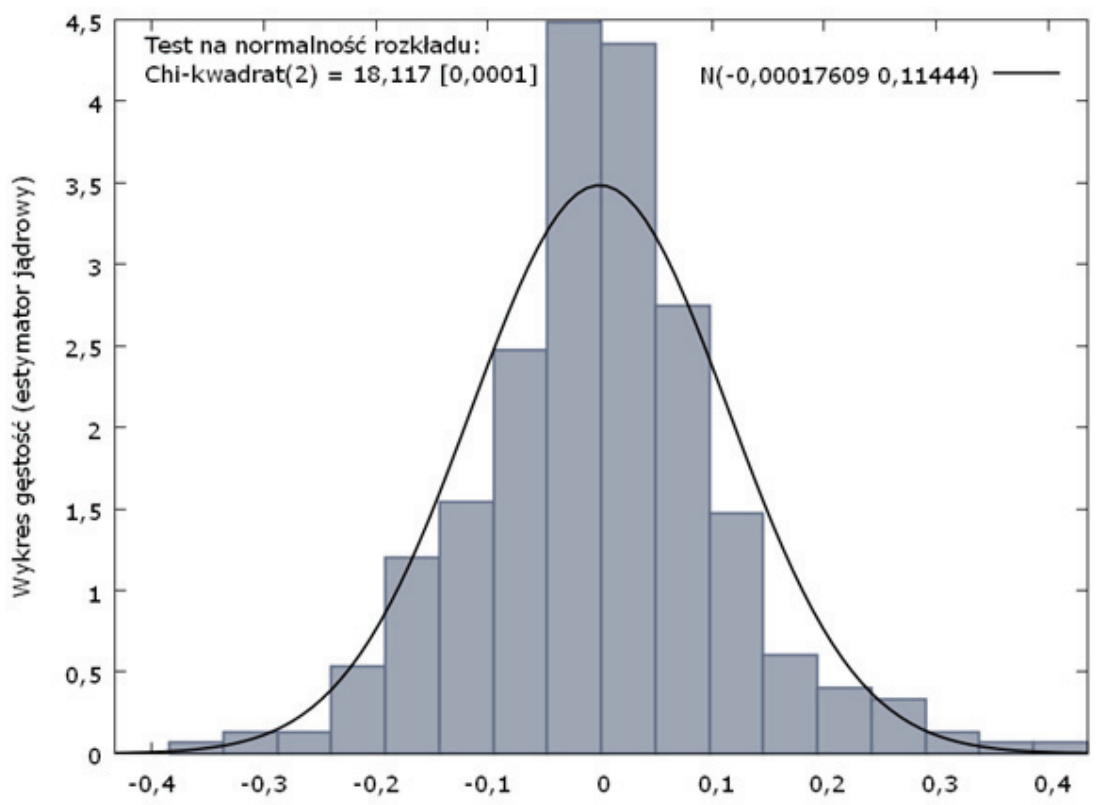

Source: calculations using GRETL and STATISTICA 12 software. 
The frequency distribution in Figure 3 shows it to be symmetric, but deviating from a normal distribution due to its large kurtosis. The DoornikHansen test (1994), with $\mathrm{p}=0.00001$, provides a strong basis on which to reject the null hypothesis that the empirical variable has a normal distribution. Nonetheless, the great majority of the residuals lie in a range from -0.1 to 1.0 , which means that the deviations between the theoretical and empirical values of the model of education quality lie within $10 \%$ of the value of that indicator. The model can thus be said to have predictive value.

\section{Conclusions}

Taxonomic analysis of education quality in rural areas has shown that in Poland the theories of polarised development are more applicable than those of endogenic development. The centre-periphery axis was observed to have an inversely proportional influence on education quality, but the primary effect was seen to come from a number of gravitational systems, in which there is observed exogenic diffusion of the effects of economic growth and progress from present and former provincial capitals into surrounding rural areas. There is consequently proposed a theoretical form of gravitation model, which might be tested in further research. Socioeconomic analysis of the determinants of education quality enabled estimation of the parameters of an econometric model which explains almost $90 \%$ of the variation in education quality in rural areas of Poland. This also confirmed the research hypothesis that exogenic socioeconomic factors are key to the effectiveness of the educational process (the education production function) in rural areas of Poland. The model shows that the strongest effect (positive on balance) on education quality is exerted by economic variables in the categories "school funding" and "income", followed by "level of education" (again with a positive influence) and then "recreation" (paradoxically having a negative influence), which turns out to be a substitutive, rather than a complementary, activity to education in rural areas. Explanatory variables and their parameters in the computed model point to the desirability of more detailed research into the quality of education in Poland, including in relation to the system of teachers' remuneration, which the computed relationships show to be ineffective. 


\section{References}

Afonso, A., Aubyn, M. S., 2004. Non-parametric Approaches to Education and Health Expenditure Efficiency in OECD Countries. Journal of Applied Economics, 8(2), pp. 227-246. Available at: http://dx.doi.org/10.2139/ssrn.498383.

Allan, J., Catts, R., 2014. Schools, social capital and space. [Article]. Cambridge Journal of Education, 44(2), pp. 217-228. Available at: http://dx.doi.org/10.1080 /0305764x.2013.863829.

Atawne, A., Hoz, R., 2012. The relations between elementary teachers' didactic knowledge and their preservice specialization, seniority in teaching, and school system. [Proceedings Paper]. 4th World Conference on Educational Sciences (Wces-2012), 46, pp. 1051-1055. Available at: http://dx.doi.org/10.1016/j. sbspro.2012.05.247.

Babarovic, T., Burusic, J., Sakic, M., 2009. Prediction of Educational Achievements of Primary School Pupils in the Republic of Croatia. Drustvena Istrazivanja, 18(4-5), pp. 673-695.

Badr, M., Morrissey, O., Appleton, S., 2003. Determinants of Educational Attainment in MENA. CREDIT Research Paper, 12, pp. 1-38.

Ballou, D., Podgursky, M., 2002. Returns to seniority among public school teachers. Journal of Human Resources, 37(4), pp. 892-912. Available at: http://dx.doi. org/10.2307/3069620.

Barro, R., Lee, J. W., 2001. Schooling Quality in a Cross-Section of Countries. Economica (68), pp. 465-488. Available at: http://dx.doi.org/10.1111/14680335.00257.

Benesova, I., Sanova, P., Laputkova, A., 2015. Public Expenditures on Education - Comparison of EU States. [Proceedings Paper]. Efficiency and Responsibility in Education 2015, pp. 25-33.

Bourdieu, P., 1994. Reproduction strategies and modes of domination, Actes de la Recherche En Sciences Sociales, 105, DEC, 3-12.

Bourdieu, P., Passeron, JC., 2006. Reprodukcja. Elementy teorii systemu nauczania [Reproduction. Elements of The Theory of Eduction]. Warszawa, Wydawnictwo Naukowe PWN.

Boyd, D., Lankford, H., Loeb, S., Wyckoff, J., 2011. Teacher Layoffs: An Empirical Illustration of Seniority Versus Measures of Effectiveness. Education Finance and Policy, 6(3), pp. 439-454. Available at: http://dx.doi.org/10.1162/edfp_a_00041

Bradford, D. F., Malt, R. A., Oates, W. E., 1969. Rising Cost of Local Public Services Some Evidence and Reflections. National Tax Journal, 22(2), pp. 185-202.

Chakraborty, K., 2009. Efficiency in Public Education - The Role of Socioeconomic Variables. Research in Applied Economics, 1(1:E5), pp. 1-18. Available at: http:// dx.doi.org/10.5296/rae.v1il.137. 
Cheung, H. Y., Chan, A. W. H., 2008. Relationships amongst cultural dimensions, educational expenditure and class size of different nations. International Journal of Educational Development, 28(6), pp. 698-707.

Available at: http://dx.doi.org/10.1016/j.ijedudev.2007.11.003.

Coleman, J. S., Campbell, E. Q., Hobson, C. J., McPartland, J., Mood, A. B., Weinfeld, F. D., et al., 1966. Equality of educational opportunity. Washington, D.C., Government Printing Office.

Comer, J. P., 2015. Developing Social Capital in Schools. Society, 52(3), pp. 225-231. Available at: http://dx.doi.org/10.1007/s12115-015-9891-5

Cooper, S. T., Cohn, E., 1997. Estimation of a frontier production function for the South Carolina educational process. Economics of Education Review, 16(3), pp. 313-327. Available at: http://dx.doi.org/10.1016/s0272-7757(96)00077-5

Czapiński, J., Panek, T., 2013. Diagnoza społeczna 2013. Warunki i jakość życia Polaków [Social Diagnosis 2013. Conditions and Quality of Polish People Life] (Vol. 7). Warsaw: Rada Monitoringu Społecznego. Available at: http://dx.doi. org/10.5709/ce.1897-9254.0295.

Darling-Hammond, L., 2000. How teacher education matters. Journal of Teacher Education, 51, pp. 166-173. Available at: http://dx.doi.org/10.1177/00224871000 51003002.

de Kool, D., Bekkers, V., 2015. The Perceived Impact of Open Inspection Data on the Quality of Education in Dutch Primary Schools: A Parent Perspective. Social Science Computer Review, 33(5), pp. 645-659.

Available at: http://dx.doi.org/10.1177/0894439314560853.

Domalewski, J., 2005. Selekcje społeczne i edukacyjne na progu szkół ponadgimnazjalnych -zróżnicowania środowiskowe [Social and Educational Selections at The Threshold of Secondary Schools - Social Diversity]. Kultura i Edukacja, 3, pp. 73-74.

Domalewski, J., Mikiewicz, P., 2004. Młodzież w zreformowanym systemie szkolnym [Youth in The Reformed School System]. Instytut Rozwoju Wsi i Rolnictwa Polskiej Akademii Nauk, rozdz. 3.

Duncombe, W., Miner, J., Ruggiero, J., 1997. Empirical evaluation of bureaucratic models of inefficiency. Public Choice, 93(1-2), pp. 1-18.

Egger, P., 2002. An Econometric View on the Estimation of Gravity Models and the Calculation of Trade Potentials. World Economy, 25(2), pp. 297-312. Available at: http://dx.doi.org/10.1111/1467-9701.00432.

Gamoran, A., Long, D., 2006. School Effects in Comparative Perspective: New Evidence from a Threshold Model. Paper presented at the Annual Meeting of the American Sociological Association. In: E. Gatnar, M. Walesiak, (eds.), 2004. Metody statystyczne analizy wielowymiarowej w badaniach marketingowych [Statistical Methods of Multidimensional Analysis in Marketing Research]. Wrocław, Wydawnictwo Akademii Ekonomicznej im. O. Langego. 
Gmerek, T., 2010. Edukacja i nierówności społeczne (wybrane problemy) [Education and Social Inequalities. Chosen Issues] In: I. Nowosad, I. Mortag, J. Ondráková (eds.), Jakość życia i jakość szkoły. Wprowadzenie w zagadnienia jakości i efektywności pracy szkoły [Quality of Life and Quality of School. Introduction to The Quality and Effectiveness of School Work]. Zielona Góra, Oficyna Wydawnicza Uniwersytetu Zielonogórskiego, pp. 39-67.

Górecki, R. B., 2010. Ekonometria. Podstawy teorii i praktyki [Econometrics. Basis of The Theory and Practice]. Warsaw, Key Text.

Guiling, P., Brorsen, B. W., Doye, D., 2009. Effect of Urban Proximity on Agricultural Land Values. Land Economics 85(2), pp. 252-264. Available at: http://dx.doi. org/10.3368/le.85.2.252

Hanushek, E., Luque, J., 2002. Efficiency and Equity in Schools Around the Word. Cambridge, National Bureau of Economic Research. Available at: http://dx.doi. org/10.3386/w8949

Heyneman, S. P., 1997. The quality of education in the Middle East and North Africa (MENA). International Journal of Educational Development, 17, pp. 449-466.

http://www.allacademic.com/meta/p103569_index.html

Ismail, N. A., Cheng, A. G., 2005. Evaluation of the Effect of Backgrounds of Students and Schools on the Mathematics and Science Achievement in the Malaysian Secondary Schools. EARCOME, 3, pp. 1-8.

Jabłoński, Ł., 2011. Kapitał ludzki w wybranych modelach wzrostu gospodarczego [Human Capital in Selected Models of Economic Growth]. Gospodarka Narodowa, 1-2, pp. 81-103.

Jacques, C., Brorsen, B. W., 2002. Relationship between types of school district expenditures and student performance. Applied Economics Letters, 9, pp. 9971002. Available at: http://dx.doi.org/10.1080/13504850210148161

Jakubowski, M., 2007. Efektywność wydatków na gimnazja [The Effectiveness of Spending on Secondary Schools]. Gospodarka Narodowa, 11-12/2007, pp. 85105.

Kalirajan, K., 2010. Stochastic varying coefficients gravity model: An application in trade analysis. Journal of Applied Statistics, 26(2), pp. 185-193. Available at: http://dx.doi.org/10.1080/02664769922520

Kipkorir, R. J., Reuben, L. C., 2015. Factors that affect students' and pupils' academic performance in Kericho West district: A case study of Seretut location. International Journal of Information Research and Review, 2(6), pp. 792-796.

Klump, R., Cabrera, C. A. M., 2007. Education and Pro-Poor Growth (Vol. 49). Frankfurt am Main: KfW Bankengruppe, Group communications.

Kremer, M., 1995. Research on Schooling: What We Know and What We Don't: A Comment. World Bank Research Observer, 10, pp. 247-254. 
Lochner, L., Moretti, E., 2004. The effect of education on crime: Evidence from prison inmates, arrests, and self-reports. American Economic Review, 94(1), pp. 155189. Available at: http://dx.doi.org/10.1257/000282804322970751

Martins, P. S., Pereirab, P. T., 2004. Does education reduce wage inequality? Quantile regression evidence from 16 countries. Labour Economics, 11, pp. 355-371. Available at: http://dx.doi.org/10.1016/j.labeco.2003.05.003

Murnane, R. J., Philips, B. R., 1981. Learning by doing, vintage and selection: Three pieces of the puzzle relating teacher experience and teaching performance. Economics of Education Review, 1, pp. 453-465. Available at: http://dx.doi. org/10.1016/0272-7757(81)90015-7

Nickerson, C. J., Morehart, M., Kuethe, T., Beckman, J., Ifft, J., Williams, R., 2012. Trends in U.S. Farmland Values and Ownership. Washington DC: U.S. Department of Agriculture, Economics Research Service, EIB-92.

Passeron, JC., 1986. Theories of Sociocultural Reproduction, International Social Science Journal , 38(4), pp. 619-629.

Pietrzak, M. B., 2010. Wykorzystanie odległości ekonomicznej w przestrzennej analizie stopy bezrobocia dla Polski [The Use of Economic Distance in The Spatial Analysis of Unemployment in Poland]. Oeconomia Copernicana, 1, pp. 79-98.

Pritchett, L., Filmer, D., 1999. What education production functions really show: a positive theory of education expenditures. Economics of Education Review, 18 (1999), pp. 223-239. Available at: http://dx.doi.org/10.1016/s02727757(98)00034-X

Roberts, B. A., 2004. A Gravity Study of the Proposed China-ASEAN Free Trade Area. The International Trade Journal 18(4), pp. 335-353. Available at: http:// dx.doi.org/10.1080/08853900490518208.

Rupasingha, A., Goetz, S. J., Freshwater, D., 2002. Social and institutional factors as determinants of economic growth: Evidence from the United States counties. [Article; Proceedings Paper]. Papers in Regional Science, 81(2), pp. 139-155. Available at: http://dx.doi.org/10.1007/s101100100091.

Salim, A., 2013. Growth of Mobile Education Platforms and the Impact on Learning in Primary Schools in Kenya. Paper presented at the 5th International Conference on Education and New Learning Technologies (EDULEARN), Barcelona, Spain.

Schneeweis, N., Winter-Ebmer, R., 2005. Peer Effects in Austrian Schools. Empirical Economics, 32(2-3), pp. 387-409. Available at: http://dx.doi.org/10.1007/978-37908-2022-5_7

Shah, A. A., Bhatti, S. H., 2012. Generic Competences and Earnings for Health Graduates. International Journal of Social Sciences and Education, 2(3), p. 503.

Shi, Y. J., Phipps, T. T., Colyer, D., 1997. Agricultural Land Values under Urbanizing Influences. Land Economics 73(1), pp. 90-100. Available at: http://dx.doi. $\operatorname{org} / 10.2307 / 3147079$. 
Shoji, M. N., Haskins, A. R., Rangel, D. E., Sorensen, K. N., 2014. The emergence of social capital in low-income Latino elementary schools. Early Childhood Research Quarterly, 29(4), pp. 600-613. Available at: http://dx.doi.org/10.1016/j. ecresq.2014.07.003

Smętkowski, M., 2013. Rozwój regionów i polityka regionalna w krajach Europy Środkowo-Wschodniej w okresie transformacji i globalizacji [Regional Development and Regional Policy in The Countries of Central-Eastern Europe in the Period of Transition and Globalization]. Warsaw, Wydawnictwo Naukowe Scholar.

Stanny, M., 2013. Przestrzenne zróżnicowanie rozwoju obszarów wiejskich w Polsce [The Spatial Differentiation of Rural Development in Poland ]. Warsaw, Instytut Rozwoju Wsi i Rolnictwa Polskiej Akademii Nauk.

Tatsi, E., Zafar, T., 2011. Social Capital and Economic Growth: Evidence from OECD Countries. Social Science Research Network Electronic Journal, pp. 1-50. doi:http://dx.doi.org/10.2139/ssrn.2370375. Available at: http://dx.doi. org/10.2139/ssrn.2370375

Tinbergen, J., 1962. Shaping the World Economy: Suggestions for an International Economic Policy. New York, The Twentieth Century Fund.

Van Rossem, R., Vermande, M., Volker, B., Baerveldt, C., 2015. Social capital in the classroom: a study of in-class social capital and school adjustment. British Journal of Sociology of Education, 36(5), pp. 669-688. Available at: http://dx.doi.org/10.1 080/01425692.2013.848779

Verbina, I., Chowdhury, A., 2004. What determines public education expenditures in Russia? [Article]. Economics of Transition, 12(3), pp. 489-508. Available at: http://dx.doi.org/10.1111/j.0967-0750.2004.00190.x

Zhou, E. Y., Cheng, C., 2010. SPSS Aided Research on Performance Management of University Teaching Staff. [Proceedings Paper]. Proceedings of the Third International Conference on Education Management Science and Engineering, pp. 999-1003. 